\title{
Kualitas Buku Teks Bahasa Indonesia Kelas VII Terbitan Kemendikbud Kurikulum 2013 (Tinjauan Atas Aspek Kesesuaian)
}

\author{
Agita Misriani \\ Sekolah Tinggi Agama Islam Negeri Curup \\ Jalan AK. Gani No. 1, Curup, Bengkulu \\ E-mail: agita_misriani@yahoo.com
}

\begin{abstract}
Abstrak: Artikel ini bertujuan mendeskripsikan buku teks Bahasa Indonesia kelas VII terbitan Kemdikbud dari segi kelayakan isi, bahasa, penyajian dan kegrafikan. Data dalam artikel ini berwujud kata, kalimat, wacana, teks dari keseluruhan isi buku teks yang diteliti, yang diperoleh dari buku teks pokok (utama) terbitan Kemdikbud yang digunakan siswa kelas VII. Instrumen dalam artikel ini mengikuti Badan Standar Nasional Pendidikan (BSNP). Untuk menganalisis data, digunakan content analyses dan untuk memeriksa keabsahan data digunakan teknik triangulasi. Hasil pembahasan menunjukkan bahwa buku teks bahasa Indonesia kelas VII terbitan Kemdikbud dalam segi isi, bahasa, dan penyajian termasuk ke dalam kategori sesuai. Namun, diperlukan revisi pada bagian keakuratan ilustrasinya, kesesuaian dengan tingkat perkembangan intelektual peserta didik, keterpahaman pesannya dan kelengkapan penyajian berdasarkan isinya. Sedangkan pada kesesuaian kegrafikan termasuk ke dalam kategori sangat sesuai. Revisi hanya pada bagian desain kulit buku agar memberikan daya tarik baik bagi peserta didik.
\end{abstract}

Kata Kunci: Bahasa Indonesia, buku teks bahasa Indonesia, kelas VII

\begin{abstract}
This study is aimed at describing the textbooks of class VII issued by Ministry of education and cultural of Indonesia (Kemendikbud), in terms of the compatibility of the content, language, presentation and layout. The data in this study consist of words, sentences, discourses and texts of the textbooks under examination, quoted from the main textbook issued by Kemendikbud as the learning source for student class VII. The instrument used in this study adopts BSNP standards. To analyze data, the study uses content analysis technique and to check the validity of the data it uses the technique of triangulation. As the results, it indicates that the Indonesian textbooks for class VII belong to appropriate category in terms of content, language and presentation. However, much revision
\end{abstract}


ISSN 2622-1810 (p) 2622-1829 (e)

\begin{abstract}
is still needed especially on the accuracy of illustrations, conformity with the level of intellectual development of students and student accessibility and the completeness of the presentation based on its content. The suitability of layout reaches very appropriate category. It only needs to revise on the design of the cover performance in order to attract student's interest.
\end{abstract}

Keywords: Indonesian textbook, Indonesian language, class VII

\title{
Pendahuluan
}

Hal yang sangat penting dalam proses kegiatan belajar mengajar hal yang adalah bahan ajar. Bahan ajar merupakan segala bahan (informasi, alat ataupun teks) yang disusun secara sistematis, yang menampilkan sosok utuh dari kompetensi yang dikuasai peserta didik dalam proses belajar (Prastowo, 2011: 31). Biasanya, bahan ajar yang digunakan dalam proses belajar mengajar adalah buku. Nasution (Prastowo, 2011: 29) mengungkapkan bahwabuku teks merupakan bahan pengajaran yang paling banyak digunakan di antara semua bahan pengajaran lainnya.

Buku teks pelajaran hendaknya mampu menyajikan bahan ajar dalam bahasa Indonesia yang baik dan benar. Sehingga bisa ditinjau kesesuaian penggunaan bahasanya wajar, menarik, dan tepat dengan perkembangan siswa atau tidak. Buku teks yang digunakan pada saat proses belajar mengajar memiliki peranan dan fungsi yang penting dalam suatu mata pelajaran tertentu. Seperti yang diungkapkan Husein (Husein, 1997: 187) semakin baik kualitas dari suatu buku pelajaran, maka akan sempurna pengajaran mata pelajaran yang ditunjangnya.

Fakta yang timbul sekarang bahwa buku pelajaran yang digunakan dalam kegaiatan belajar mengajar tidak memenuhi kriteria suatu buku pelajaran yang ideal, yang digunakan oleh peserta didik dalam mencapai suatu kompetensi. Dalam pembelajaran bahasa Indonesia, buku teks pun tidak luput dari suatu kekurangan.

Berdasarkan fakta yang terjadi, maka penilaian terhadap buku teks berpusat terhadap aspek bacaan, baik hal-hal yang berhubungan dengan penggunaan wacana, paragraf, kalimat dan kata yang dipandang dari kaidah bahasa Indonesia dan kesesuaian bahasa dengan peserta didik. Berdasarkan penilaian itu, bahasa Indonesia yang digunakan dalam buku teks pelajaran dapat berfungsi sebagai media menyampaikan pesan. Oleh 
karena itu, dalam suatu buku teks harus memiliki kesesuaian dari segi isi, bahasa, penyajian dan kegrafikan yang baik agar penyampaian Kompetensi inti dan kompetensi dasar dalam mata pelajaran bahasa Indonesia khususnya dapat memberikan hasil yang baik bagi peserta didik.

Dalam PP No. 19/2005 pasal 43 ayat (5) bahwa kesesuaian isi, bahasa, penyajian, dan kegrafikan buku teks pelajaran dinilai oleh BSNP dan ditetapkan dengan Peraturan Menteri. Aspek-aspek yang berkaitan dengan kesesuaian isi, bahasa, penyajian maupun kegrafikan harus ada dalam suatu buku pelajaran yang baik.

Buku teks bahasa Indoensia yang diterbitkan oleh Kemendikbud RI tahun 2013 yang berjudul "Bahasa Indonesia Wahana Pengetahuan" yang diperuntukkan untuk siswa kelas VII SMP/ MTS yang sesuai dengan penerapan kurikulum 2013 ini, yang terdiri dari VIII bab ditemukan beberapa kekurangan kata seperti fitoplankton, intensifikasi merupakan penggunaan bahasa asing yang tidak sesuai dengan tingkat pemahaman siswa kelas VII. Pada halaman 94 bab IV tentang Teknologi Tepat Guna ilustrasi seperti gambar yang ada tidak dapat merangsang siswa untuk berpikir kreatif, karena gambar yang diambil dari internet kurang jelas. Begitu juga halnya di bab II tentang Pengenalan Budaya dengan materi penyusunan teks deskriptif secara berkelompok pada halaman 39 terdapat latihan soal - soal esai yang diisi berdasarkan gambar yang ada. Pertanyaan - pertanyaan tersebut dapat dijawab siswa dengan benar dan tepat bila gambar yang ditampilkan memiliki kontras warna yang jelas. Namun, pada ilustrasi gambar yang ada tari saman yang dijadikan ilustrasi soal, terlihat gelap tidak jelas kostum yang digunakan itu apakah merah keemasan atau orange kekuningan. Sehingga akan menimbulkan variasi jawaban dari siswa yang dinilai dapat merugikan siswa karena gambar yang tidak jelas untuk digunakan dalam evaluasi pembelajaran.

Artikel yang relevan yakni dilakukan oleh Muslimin, mahasiswa Universitas Negeri Gorontalo pada tahun 2011 lalu. Dalam artikelnya yang berjudul Analisis Buku Teks Bahasa Indonesia Untuk SMP kelas VII dengan Pendekatan Tematik, Muslimin fokus meneliti tingkat keterbacaan teks membaca saja pada buku teks bahasa Indonesia tersebut. Hasil dari artikel ini, yakni dalam pembelajaran bahasa siswa 
tidak hanya berkutat pada konstrak teori bahasa, tetapi ditekankan pada sikap dan pemakaian bahasa yang kontekstual. Kompetensi dasar yang terdapat dalam standar isi dijabarkan dalam model-model pembelajaran yang kontekstual, melibatkan pengalaman siswa. Dalam satu kompetensi dasar yang dipelajari, siswa diajak untuk melakukan berbagai keterampilan berbahasa pada konteks tertentu. Selain itu, proses pembelajaran juga melibatkan pengalaman siswa dengan materi yang dekat dengan kehidupan mereka. Dengan demikian, siswa lebih mudah untuk memahami dan mengaplikasikan kompetensi dasar yang dipelajari. Pendekatan active learning yang diterapkan dalam buku ini dilengkapi dengan model-model pembelajaran yang bervariasi sehingga siswa tidak merasa bosan.

Menurut penulis, artikel Muslimin pada buku teks bahasa Indonesia kelas VII ini, hanya fokus pada pendekatan yang digunakan dalam buku teks dan juga model-model pembelajarannya saja Muslimin tidak meneliti dari segi isi, penyajian, bahasa serta kegrafikan dalam buku teks ini.

Artikel ini tentunya berbeda dengan artikel yang telah dilakukan oleh Muslimin. Artikel ini akan mengupas secara keseluruhan kesesuaian uraian materi dari keempat aspek berbahasa, yakni menyimak, membaca, menulis dan berbicara.

Berdasarkan latar belakang di atas, masalah yang akan diteliti dalam artikel ini mengenai kualitas buku teks yang dirumuskan sebagai berikut: bagaimana kesesuaian Buku teks bahasa Indonesia Kurikulum 2013 yang digunakan di SMP kelas VII berdasarkan dari aspek kesesuaian isi, kesesuaian kebahasaan, kesesuaian penyajian dan kesesuaian kegrafikan?

Adapun tujuan dari artikel ini untuk mengetahui kekesuaian Buku Teks Kurikulum 2013 yang digunakan di SMP KELAS VII. Tujuan ini secara rincinya untuk mengetahui kesesuaian dalam keempat aspek dari buku bahan ajar tersebut di atas.

\section{Metode Penelitian}

Artikel ini berupaya mendapatkan gambaran mengenai bahan ajar membaca dalam buku teks Bahasa Indonesia yangditerbitkan oleh 
Kemendikbud. Oleh karena itu, artikel ini menggunakan metode deskriptif. Data dalam artikel ini berupadata yang berwujud kata, kalimat, wacana, teks dari keseluruhan isi buku teks yang diteliti. Adapun sumber data dalam artikel ini berupa buku teks pokok (utama) terbitan Kemdikbud yang digunakan siswa kelas VII.

Data adalah fakta empirik yang dikumpulkan oleh peneliti untuk kepentingan memecahkan masalah atau menjawab pertanyaan artikel. Data artikel dapat berasal dari berbagai sumber yang dikumpulkan dengan menggunakan berbagai teknik selama kegiatan artikel berlangsung. Data dalam artikel ini berupadata yang berwujud kata, kalimat, wacana, teks dari keseluruhan isi buku teks yang diteliti.

Sumber data dalam artikel disesuaikan dengan latar belakang dan tujuan artikel. Sumber data adalah tempat data itu diambil atau diperoleh Arikunto (Arikunto, 2010: 172). Adapun sumber data dalam artikel ini berupa buku teks pokok (utama) terbitan Kemdikbud yang digunakan siswa kelas VII.

Proses pengumpulan data pada artikel ini dilakukan dengan teknik dokumentasi, teknik observasi. Teknik dokumentasi ini dilakukan dengan memilih buku teks yang akan dikaji yakni Buku Bahasa Indonesia SMP kelas VII yang telah dinyatakan lulus uji kesesuaian dan diterbitkan oleh Kemdikbud. Menurut

Arikunto (Arikunto, 2010: 274) teknik dokumentasi, yaitu mencari data mengenai hal-hal atau variabel yang berupa catatan, transkrip, buku, surat kabar, majalah, prasasti, notulen, rapat, lagenda dan sebagainya. Artikel ini, data dari kualitas buku yang dilihat dari segi kesesuaian isi, bahasa, penyajian dan kegrafikan yang digunakan di kelas VII dan sesuai dengan kurikulum 2013 dikumpulkan dengan teknik pencatatan.

Instrumen artikel ini menggunakan dokumentasi dan format pencatatan yang diterapkan dalam Instrumen BSNP (Badan Standar Nasional pendidikan) (Muslich, 2010: 291) Pemberian skor terhadap buku teks bahasa Indonesia terbitan Kemendikbud.

Artikel terhadap buku teks ini dilakukan oleh penulis dan 2 orang guru bahasa Indonesia kelas VII dengan menggunakan instrumen BSNP. Dari artikel yang dilakukan menunjukkan bahwa, terdapat beberapa 
perbedaan dalam kesesuaian isi, bahasa, penyajian dan kegrafikan. Namun, perbedaan pada hasil penilaian tersebut tidak terlalu signifikan.

Teknik yang digunakan untuk memeriksa keabsahan data dalam artikel ini adalah teknik triangulasi. Teknik Triangulasi adalah teknik pemeriksaan keabsahan data dengan memanfaatkan sesuatu di luar data untuk keperluan pengecekan atau perbandingan data (Moleong, 1998: 178). Dari pendapat tersebut bahwa teknik pemeriksaan keabsahan data dalam artikel ini adalah membandingkan data yang didapat dari triangulator (pengamat/peneliti lain) dengan menggunakan instrumen BSNP.

\section{Landasan Teoritis}

Salah satu bahan ajar tertulis dalam kegiatan belajar mengajar adalah buku. Buku bermula dari suatu gagasan, pemikiran, pesan, pengalaman, ilmu bahkan khayalan seseorang yang ingin disampaikan kepada orang lain (Maharani, 2009: 85). Buku teks pelajaran bahasa Indonesia merupakan buku pelajaran dalam bidang studi bahasa indonesia yang disusun oleh para pakar dalam bidang studi bahasa Indonesia untuk maksud dan tujuan instruksional, yang dilengkapi dengan sarana pengajaran yang serasi dan mudah dipahami oleh guru dan siswa, sehingga dapat menunjang pengajaran bahasa Indonesia (Tarigan dan Djago Tarigan, 1993:13).

Buku teks bahasa Indonesia memiliki kedudukan penting dalam konteks buku pelajaran. Sebagai fungsi bahan yang digunakan untuk pelatihan bahasa lisan dan tulis, sebagai sumber kegiatan siswa dalam berkomunikasi, dan sebagai acuan siswa untuk belajar tata bahasa (Cunningsworth dalam Sumardi, 2000: 7). Menurut Tarigan dan Djagon Tarigan (Tarigan dan Djagon Tarigan, 1986: 29) ada empat dasar atau patokan yang digunakan dalam pengklasifikasian buku teks yaitu:

1. Berdasarkan mata pelajaran atau bidang studi (terdapat di SD, SMP, SMA).

2. Berdasarkan mata kuliah bidang yang bersangkutan (terdapat di perguruan tinggi).

3. Berdasarkan penulisan buku teks (mungkin di setiap jenjang pendidikan). 
4. Berdasarkan jumlah penulis buku teks.

Buku teks memiliki fungsi yang beragam, menurut Nasution (Pratowo, 2011: 169) bahwa buku teks berfungsi sebagai: a) sebagai bahan referensi atau bahan rujukan oleh peserta didik, b) sebagai bahan evaluasi, c) sebagai alat bantu pendidik dalam melaksanakan kurikulum, d) sebagai salah satu penentu metode atau teknik pengajaran yang akan digunakan pendidik, dan e) sebagai sarana untuk peningkatan karier dan jabatan.

Analisis merupakan kajian yang dilaksanakan terhadap sebuah bahasa untuk meneliti struktur bahasa tersebut secara mendalam (www. Wikipedia.com 2012). Analisis merupakan pembahasan yang dikaji secara terperinci (details) berdasarkan struktur tertentu yang memiliki metode, konsep ilmiah hingga memperoleh hasil yang mendalam. (Webster, 1987: 86). Analisis buku teks merupakan pembahasan yang dikaji dalam buku teks berdasarkan isi pelajaran suatu bidang studi, penulis, relevansi bidang studi tertentu, kualitas standar untuk menunjang pengajaran dan perlengkapan sarana pada satuan pendidikan.

Buku teks yang baik harus relevan dengan implementasi kurikulum. Tarigan \& Tarigan (Tarigan dan Djagon Tarigan, 2009: 89) menjelaskan bahwa kriteria buku yang baik merupakan (a) buku teks harus memiliki landasan, prinsip, atau sudut pandang tertentu yang menjiwai atau melandasi buku teks secara keseluruhan,( b)kejelasan konsep, (c) relevan dengan kurikulum, (d) menarik minat, (e) menumbuhkan motivasi, (f) menstimulasi aktivitas siswa, (g) ilustratif, (h) komunikatif. Selain itu, sebuah buku teks harus memiliki kelayakan untuk digunakan sebagai bahan ajar. Pada Pedoman BNSP (Muslich, 2010: 291), buku teks yang berkualitas wajib memenuhi empat unsur kelayakan, yaitu kelayakan isi, kelayakan penyajian, kelayakan kebahasaan, kelayakan kegrafikan.

\section{Hasil Temuan dan Pembahasan}

Berdasarkan artikel yang telah dilakukan oleh peneliti yakni analisis mengenai kesesuaian isi, bahasa, penyajian dan kegrafikan dalam buku teks Bahasa Indonesia kelas VII kurikulum 2013, adapun deskripsi buku tersebut sebagai berikut: 


$\begin{array}{ll}\text { Judul buku } & \text { : Bahasa Indonesia Wahana Pengetahuan } \\ \text { Penerbit } & : \text { Kemendikbud } \\ \text { Tahun terbit } & : 2013 \\ \text { Kelas } & : \text { VII } \\ \text { Penulis } & \text { : Dr. Fairul Zabadi, Dr. Mu'jizah, Dra. Dad } \\ & \text { Murniah, M.Hum., Drs. Sutejo } \\ \text { Jumlah Halaman } & : \text { 226 Halaman } \\ \text { Jumlah Bab } & : 8 \text { Bab }\end{array}$

Dari hasil pengumpulan data yang telah dilakukan pada buku teks bahasa Indonesia kelas VII terbitan Kemdikbud, maka hasilnya adalah sebagai berikut.

\section{Kesesuaian Isi}

Temuan data terhadap kesesuaian isi yang terdiri dari subkomponen kesesuaian uraian materi dengan $\mathrm{KI}$ dan $\mathrm{KD}$, keakuratan materi, dan pendukung materi pembelajaran menunjukkan hasil sebagai berikut:

Tabel

Tingkat Kesesuaian Isi dalam buku teks Bahasa Indonesia

\begin{tabular}{|l|l|c|c|}
\hline \multicolumn{1}{|c|}{$\begin{array}{c}\text { SUB } \\
\text { KOMPONEN }\end{array}$} & \multicolumn{1}{|c|}{ BUTIR } & SKOR & KET \\
\hline $\begin{array}{l}\text { Kesesuaian } \\
\text { uraian materi } \\
\text { dengan KI dan } \\
\text { KD }\end{array}$ & 1. Kelengkapan Materi & 3 & S \\
\cline { 2 - 4 } & 2. Kedalaman Materi & 3 & S \\
\cline { 2 - 4 } & 3. Pilihan tema & 3,3 & S \\
\hline $\begin{array}{l}\text { Keakuratan } \\
\text { Materi }\end{array}$ & 4. Keakuratan fakta dan konsep & 3,7 & SS \\
\cline { 2 - 4 } $\begin{array}{l}\text { 5. Keakuratan ilustrasi } \\
\text { Pendukung } \\
\text { materi }\end{array}$ & $\begin{array}{l}\text { 6. Kesesuaian dengan } \\
\text { perkembangan ilmu }\end{array}$ & 2,7 & S \\
\hline
\end{tabular}




\begin{tabular}{|l|l|c|c|}
\hline pembelajaran & $\begin{array}{l}\text { 7. Kesesuaian } \\
\text { fitur/contoh/latihan/rujukan }\end{array}$ & 3,3 & $\mathrm{~S}$ \\
\cline { 2 - 4 } & 8. Kontekstual & 3 & $\mathrm{~S}$ \\
\cline { 2 - 4 } & $\begin{array}{l}\text { 9. Sains, Lingkungan, Teknologi, } \\
\text { Masyarakat }\end{array}$ & 3,3 & $\mathrm{~S}$ \\
\hline Jumlah & \multicolumn{2}{|c|}{28.6} & $\mathrm{~S}$ \\
\hline Nilai & 3,17 & \\
\hline
\end{tabular}

Dari tabel tersebut, diketahui bahwa hasil dari analisis untuk kesesuaian isi buku Bahasa Indonesia terbitan Kemdikbud ini termasuk ke dalam kategori Sesuai. Ketiga subkomponen pada aspek ini semuanya termasuk dalam kategori sesuai namun, 9 butir yang ada dalam subkomponen tidak hanya masuk kategori sesuai melainkan ada yang masuk dalam kategori sangat sesuai. Buku Bahasa Indonesia terbitan Kemdikbud ini memiliki 8 bab pokok bahasan dengan 17 submateri, dari 8 bab tersebut memuat KI dan KD secara lengkap. Berikut ini dipaparkan contoh-contoh tingkat Kesesuaian berkenaan isi materi yang sesuai.

\section{Contoh Tugas Mencari dan Mengidentifikasi Teks Eksposisi}

"Carilah teks eksposisi tentang teknologi tepat guna di media massa cetak, seperti koran atau majalah! Identifikasilah teks yang kamu temukan itu betul-betul merupakan eksposisi! Kamu juga boleh mencari teks eksposisi di internet. Perlu kamu ingat lagi bahwa teks eksposisi bertata organisasi khusus, yaitu pernyataan pendapat, argumentasi, dan penegasan ulang pendapat. Sebagai perbandingan, kamu boleh melihat kembali teks yang telah dicontohkan di atas. Seandainya teks yang kamu temukan itu bukan teks eksposisi, modifikasilah agar menjadi teks eksposisi yang bagus!" (Kemendikbud: 5) 
Contoh tersebut menunjukkan bahwa peserta didik diberikan tugas untuk mengidentifikasi kekurangan dari teks yang mereka cari di media cetak, dan memperbaiki teks wacana yang mereka dapatkan menjadi sebuah teks wacana yang baik yang sesuai dengan kompetensi dasar yang ada. Kedalaman materi pada teks di atas jelas, menunjukkan pemahaman siswa terhadap teks eksposisi dan juga menemukan kekurangan yang terdapat pada teks ekpsosisi yang tentunya sesuai dengan tuntutan kompetensi dasar yang ada. Selain contoh di atas, terdapat juga contoh lain yang sesuai dengan Kompetensi Dasar, seperti contoh berikut.

\section{Contoh Tugas Menyusun Teks Tanggapan Deskriptif}

a. "Saksikanlah pertunjukan tari di daerahmu bersama orang tuamu! Tanyakanpada pengelola tari, apa saja yang digunakan agar tari itu dapat tampil di pentas?Bagaimana tanggapan masyarakat tentang tari itu?

b. Tanyakan pada orang tuamu apa manfaatnya menyaksikan pertunjukkan tari!

c. Buatlah laporan hasil menonton dan hasil wawancara dengan orang tua itu dalam bentuk laporan tulis deskriptif! Serahkan kepada guru untuk dievaluasi!

d. Pada bagian ini kamu diminta membuat teks tanggapan deskriptif secara mandiri. Temanya bergantung pada budaya Indonesia yang kamu sukai. Untuk melatih bahasa tulis, kamu lakukan tugas berikut!

e. Tentukan tema yang akan kamu tulis yang berhubungan dengan budaya Indonesia!

f. Berdasarkan struktur teks deskriptif, tentukan juga bagian-bagian teks yang akan kamu susun! Buatlah karangan teks tersebut! Jika kamu kurang memahaminya,tanyakan kepada teman atau guru!

g. Setelah teks tanggapan deskriptif yang kamu buat selesai, minta pendapat gurumu sebelum dipublikasi! “

(Kemendikbud: 7)

Contoh di atas menunjukkan salah satu materi yang sesuai dan dengan kompetensi dasar. Siswa diminta untuk menyusun teks deskriptif yang berhubungan dengan budaya Indonesia yang ada. Pemilihan tema mengenai pertunjukan tari daerah masing - masing peserta didik, 
merupakan pemilihan tema yang tepat karena peserta didik dapat mengenal dengan cermat budaya daerah masing - masing.

Keakuratan materi dalam artikel ini terdiri atas keakuratan fakta dan konsep serta ilustrasi. Untuk kesesuaian ilustrasi dalam buku Bahasa Indonesia terbitan Kemdikbud ini, bersifat penunjang materi yang disampaikan kepada peserta didik. Ilustrasi ini harus sesuai dengan materi yang disajikan, agar materi tersebut bisa dipahami oleh peserta didik. Di bawah ini juga merupakan contoh materi yang sesuai.

\section{Contoh Tingkat Kesesuaian Isi Materi yang Sangat Sesuai}

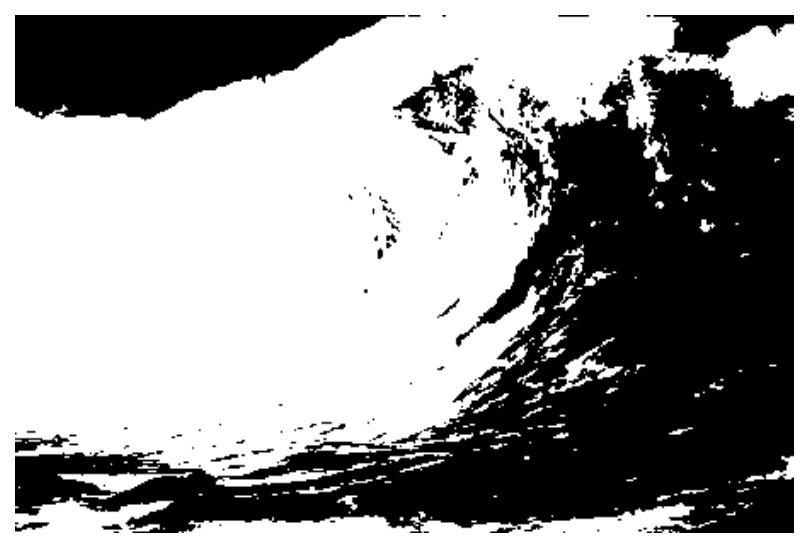

Gambar Gelombang Laut Ketika Tsunami Terjadi Sumber http://indonesiarayanews.com

a. "Kata "tsunami" berasal dari bahasa Jepang "tsu" yang berarti 'pelabuhan' dan "nami" yangberarti 'gelombang'. Namun, para ilmuwan mengartikan tsunami dengan 'gelombang pasang' (tidal wave) atau dikenal juga dengan sebutan gelombang laut karena gempa (seismic sea waves). Tsunami adalah serangkaian gelombang yang terbentuk karenagempa atau letusan gunung berapi di bawah laut atau di daratan dekat pantai. Gelombangnya yang besar menyebabkan banjir dan kerusakan saat menghantam pantai.

b. Tsunami tercipta saat permukaan dasar laut bergerak naik turun di sepanjang patahan selama gempa terjadi. Patahannya menyebabkan keseimbangan air menjadi terganggu. Makin besar daerah patahan yang terjadi, makin besar pula tenaga gelombang 
yang dihasilkan. Selain itu, tsunami juga tercipta karena meletusnya gunung berapi yang menyebabkan pergerakan air di laut atau perairan sekitarnya sangat tinggi. Gelombang yang besar menyebabkan banjir dan kerusakan saat menghantam pantai.

c. Gelombang tsunami yang terjadi di laut melaju lebih cepat daripada gelombang normal. Gelombang tersebut menyebar ke segala arah dengan ketinggian 30 sampai dengan 50 meter dan kecepatan sekitar $800 \mathrm{~km} / \mathrm{jam}$. Ketika gelombang tsunami memasuki airdangkal, kecepatannya akan menurun dan ketinggiannya akan bertambah. Ketinggian gelombang itu juga bergantung pada bentuk pantai dan kedalamannya. Gempa bumi yang tejadi di dasar laut sangat berpotensi menimbulkan tsunami dan sangat berbahaya bagi manusia. Kamu tidak perlu khawatir karena tidak semua gempa dan letusan gunung berapi menyebabkan tsunami dan tidak semua tsunami menimbulkan gelombang besar. Tsunami selalu menyebabkan kerusakan besar bagi manusia. Kerusakan yang paling besar terjadi ketika gelombang besar tsunami itu mengenai permukiman manusia sehingga menyeret apa saja yang dilaluinya."

(Buku teks Bahasa Indonesia, Hal:32)

Wacana di atas mengenai Tsunami yang terdapat dalam bab $\mathrm{V}$. Wacana mengenai tsunami tersebut menjelaskan pengertian tsunami, asal kata tsunami lalu peristiwa berlangsungnya tsunami itu sendiri, serta akibat yang ditimbulkan oleh peristiwa tsunami yang disajikan dengan diikuti ilustrasi kejadian tsunami.

Materi pendukung dalam buku Bahasa Indonesia terbitan Kemdikbud ini secara keseluruhan sudah kontekstual. Karena di dalam buku ini sudah menunjukkan materi-materi yang disesuaikan untuk setiap daerah, sehingga buku ini bisal digunakan diseluruh penjuru. Misalnya saja, di dalam buku ini menyajikan materi tentang peristiwa alam, lalu kebudayaan Indonesia, kelautan, remaja dan karakternya yang disajikan secara sederhana.

Buku Bahasa Indonesia terbitan Kemdikbud ini juga telah disesuaikan dengan perkembangan ilmu. Misalnya, di bab terakhir bagian buku ini pada halaman 199 menyajikan wacana seorang siswa pada tahun 2010 
mendapat medali emas setelah memecahkan teka - teki Michael Jackson. Artinya materi digunakan terbilang masih baru dan mengikuti perkembangan ilmu yang ada dan dapat disampaikan kepada peserta didik khususnya kelas VII pada jenjang Sekolah Menengah Tingkat Pertama.

\section{Kesesuaian Bahasa}

Kesesuaian bahasa dalam artikel ini merupakan penggunaan bahasa yang sesuai dengan tingkat pemahaman peserta didik, khususnya kelas VII. Penggunaan bahasa juga harus sesuai dengan tata bahasa atau Ejaan Yang Disempurnakan (EYD).

Tabel

Tingkat Kesesuaian Bahasa dalam Buku Teks

\begin{tabular}{|c|c|c|c|}
\hline $\begin{array}{c}\text { SUB } \\
\text { KOMPONEN }\end{array}$ & BUTIR & SKOR & KET \\
\hline \multirow{2}{*}{$\begin{array}{l}\text { kesesuaian } \\
\text { dengan tingkat } \\
\text { perkembangan } \\
\text { peserta didik }\end{array}$} & $\begin{array}{l}\text { Kesesuaian dengan tingkat } \\
\text { perkembangan intelektual peserta } \\
\text { didik. }\end{array}$ & 2,3 & KS \\
\hline & $\begin{array}{l}\text { Kesesuaian dengan tingkat } \\
\text { perkembangan sosial emosional } \\
\text { peserta didik }\end{array}$ & 3 & $S$ \\
\hline \multirow[t]{3}{*}{ Komunikatif } & Keterpahaman Pesan & 2,3 & KS \\
\hline & Ketepatan tata bahasa & 2,7 & S \\
\hline & Kebakuan istilah dan symbol & 4 & SS \\
\hline \multirow{2}{*}{$\begin{array}{l}\text { keruntutan dan } \\
\text { kesatuan } \\
\text { gagasan }\end{array}$} & Keruntutan dan keterpaduan bab & 4 & SS \\
\hline & Ketertautan antar bab, sub - bab, & 3,7 & S \\
\hline
\end{tabular}


ISSN 2622-1810 (p) 2622-1829 (e)

\begin{tabular}{|l|l|c|c|}
\hline & paragraf, kalimat & & \\
\cline { 1 - 3 } Jumlah Skor & 22 & \multirow{2}{*}{ S } \\
\cline { 1 - 3 } Nilai & 3,14 & \\
\hline
\end{tabular}

Dari hasil artikel yang dilakukan pada instrumen ke 2 mengenai kesesuaian bahasa dalam buku Bahasa Indonesia terbitan Kemdikbud termasuk dalam kategori sesuai. Ketujuh butir yang ada dalam aspek ini tidak hanya termasuk dalam kategori yang sesuai namun, ada butir yang termasuk dalam kategori kurang sesuai dan sangat sesuai.

Bahasa yang digunakan dalam buku ini Kurang sesuai untuk peserta didik kelas VII, karena di dalam buku ini terdapat istilah-istilah yang belum lazim terdengar oleh mereka. Seperti contoh berikut yang materinya terdapat beberapa istilah.

Contoh Kesesuaian Bahasa yang Kurang Sesuai

\section{Kegiatan 2}

\section{Penyusunan Teks Eksposisi secara Berkelompok}

Pada Kegiatan 2 berikut kamu diajak untuk menyusun teks yang telah kamu baca diatas secara berkelompok. Tiap-tiap kelompok terdiri atas 3-5 siswa. Tiap kelompok diharapkan menggunakan kata-kata sendiri tanpa mengurangi isi teks tersebut. Pada Tugas I dan Tugas II ini tiap kelompok diharapkan menyusun tulisan atau karangan antara 12-15 kalimat. Dalam menyusun teks itu tiap kelompok dapat menggunakan alat kohesi leksikal maupun kohesi gramatikal. Di samping itu, kamu juga harus memanfaatkan konjungsi, antara lain, penambahan, perbandingan, waktu, sebab akibat, dalam susunan kalimat majemuk setara maupun kalimat majemuk bertingkat. (Fairul Zabadi dkk, 2013: 16)

Teks di atas menunjukkan adanya penggunaan istilah yang masih sangat asing bagi peserta didik, seperti kata "kohesi leksikal" dan "kohesi gramatikal". Tugas yang diberikan pada kegiatan 2 ini tidak akan 
memberikan hasil yang maksimal bagi peserta didik, karena mereka akan kebingungan untuk menyelesaikan tugas yang perintahkan, dan sebelum diberikannya kegiatan 2 ini, tidak ada penjelasan mengenai apa itu kohesi gramatikal dan kohesi leksikal. Ini akan mempengaruhi hasil yang akan dicapai siswa pada akhir pembelajaran.

Buku ini termasuk buku yang dekat dengan perkembangan sosial Peserta didik, karena buku ini memancing peserta didik untuk ikut merasakan sesuatu hal yang terdapat dari materi. Misalnya mengaitkan kehidupan nyata siswa dengan materi yang ada, pentingnya menjaga lingkungan, melestarikan kebudayaan seperti yang disajikan pada contoh berikut ini.

\section{Contoh Kesesuaian Bahasa yang Sesuai}

"Berikut ini ditampilkan teks laporan hasil observasi yang harus kamu pelajari. Dalammembaca teks "Cinta Lingkungan", tunjuklah salah seorang teman untuk membaca dengan suara lantang dan kamu menyimaknya!

\section{Cinta Lingkungan}

1. Lingkungan hidup adalah segala sesuatu yang ada di sekitar manusia danberhubungan timbal balik. Lingkungan hidup ini mencakupi benda hidup dan benda mati. Benda hidup perlu makanan dan berkembang biak seperti manusia, binatang, dan tumbuhan. Benda mati antara lain tanah, air, api, batu, dan udara. Jika terpelihara dengan baik, lingkungan hidup itu dapat menciptakan masyarakat yang sehat, aman, tenteram, lahir dan batin.

2. Indonesia merupakan paru-paru dunia kedua. Indonesia memiliki hutan lebat yang memberikan banyak oksigen. Di negara ini terdapat tumbuh-tumbuhan dan hewan yang khas, seperti matoa, kayu cendana, burung cendrawasih, orang utan, dan komodo.

3. Ekosistem di Indonesia yang masih terjaga, salah satunya, adalah kawasan Gunung Kidul. Di daerah itu sungai di bawah tanah airnya melimpah. Di guadan sekitar sungai masih dihuni segerombolan kelelawar dan fitoplankton. 
Fitoplankton itu menjadi makanan ikan sehingga ikan berkembang biak dengan baik. Hewan-hewan melata atau reptil, seperti ular, kadal, dan tokek masih berkeliaran. Burung-burung kecil berkicau, musang berlari-larian, ayam berkokok dan berbagai serangga hidup saling pengaruh". (Fairul Zabadi dkk, 2013: 9)

Teks di atas merupakan salah satu teks yang akrab dengan lingkungan sehari-hari peserta didik. Teks Cinta Lingkungan, bukanlah teks yang asing bagi peserta didik, karena teks tersebut disajikan dengan memuat hal-hal yang pernah dilakukan atau ditemui peserta didik di lingkungan kehidupan mereka.

Dalam Komponen komunikatif, buku Bahasa Indonesia terbitan Kemdikbud ini kurang komunikatif. Karena di dalam buku ini masih banyak ditemukannya penggunaan bahasa asing yang masih cukup dominan dan ini diluar jangkauan pemahaman berpikir peserta didik. Adapun wacana yang kurang sesuai bahasanya seperti yang terdapat pada wacana bab 1 halaman 10 di bawah ini:

\section{Contoh Kesesuaian Bahasa yang Kurang Sesuai}

"Taman Nasional berfungsi untuk pelestarian habitat hewan dan tumbuhan yang hidup di wilayah Indonesia.

Taman Nasional didirikan untuk melestarikan lingkungan alam dan mengembangkan pengetahuan.

Wilayah kawasan taman nasional memiliki sumber daya alam hayati dan ekosistem yang khas, unik, utuh, dan alami serta mempunyai luas wilayah yang cukup untuk kelangsungan proses ekologis secara alami dengan pembagian zona inti, zona pemanfaatan, dan zona rimba.

Taman Nasional ini sangat berguna untuk artikel dan pengembangan ilmu pengetahuan, misalnya untuk pengamatan fenomena alam, konservasi alam, pemanfaatan air serta energi air panas, dan angin serta wisata alam.

Di Taman Nasional ini berbagai habitat hidup dengan aman dan alami, misalnya orang utan dengan leluasa berayun dari satu pohon 
ke pohon lain dan dengan lleluasanya juga ia memilih pucuk-pucuk daun untuk dimakan.

Taman Nasional adalah kawasan pelestarian alam yang mempunyai ekosistem asli dan dikelola dengan bersistem untuk keperluan berbagai artikel, perkembangan ilmu pengetahuan, pendidikan, dan pariwisata." (Fairul Zabadi dkk, 2013: 10)

Wacana di atas yang terdapat pada bab 1 Cinta Lingkungan Hidup menunjukkan kata "ekosistem, ekologis dan zona," yang masih asing bagi peserta didik, apalagi peserta didik yang berada di daerah. Hal ini jelas akan mengurangi pemahaman siswa terhadap teks yang disajikan di dalam buku. Penulisan miring yang harusnya digunakan untuk bahasa asing, tetapi diterapkan di dalam bahasa Indonesia seperti yang terdapat pada halaman 53 seperti penulisan "pantun kilat, talibun dan pantun biasa" yang seharusnya ditulis biasa "pantun kilat, talibun dan pantun biasa". (Fairul Zabadi dkk, 2013: 10)

Komponen selanjutnya, yaitu keruntutan dan kesatuan gagasan yang terdiri dari keruntutan dan keterpaduan bab,ketertautan antar bab, subbab, paragraf, kalimat. Bila kita tinjau dari ketertautan antar bab buku ini tidak memiliki ketertautan antar bab. Karena antara bab 1 sampai bab 8 tidak ada keterkaitannya sama sekali. Untuk ketertautan antara bab dan sub bab, buku ini memperlihatkan ketertautannya, karena antara pokok bahasan dengan sub bahasannya ada ketertautan yang mempertegas materi yang akan disampaikan kepada peserta didik. Misalnya, buku teks ini memuat tema pembelajarannya Cinta Lingkungan, sub babnya memahami lingkungan melalui sastra. Selain itu, temanya Pengenalan budaya Indonesia, sub babnya Tari saman. Ini bukti bahwa antar bab dengan sub-bab ada ketertautan. Contoh di bawah ini menunjukkan ketertautan antara pokok bahasan dan sub bahasannya yang sangat sesuai.

\section{Contoh Kesesuaian Bahasa yang Sangat Sesuai}

“A. Subtema 1 Teknologi Tepat Guna dan Pemberdayaan Ekonomi Masyarakat

Teknologi tepat guna merupakan teknologi yang telah dikembangkan secara tradisional.Pengenalannya banyak ditentukan 
oleh keadaan lingkungan dan mata pencaharian pokok masyarakat setempat.

Dengan adanya penerapan ini diharapkan masyarakat berubah dan mengerti manfaat teknologi tepat guna. Mereka juga mampu menggunakan teknologi tepat guna tersebut dengan sebaik-baiknya. Dengan demikian, penggunaan teknologi tepat guna tersebut bermanfaat bagi masyarakat, yaitu dapat memenuhi kebutuhan individu atau masyarakat karena kebutuhan masyarakat makin hari makin meningkat.

Kegiatan 1

Pemodelan Teks Eksposisi

Pada Kegiatan 1 ini kamu diajak belajar tentang teks eksposisi yang berjudul "Teknologi Tepat Guna dan Pemberdayaan Ekonomi Masyarakat".

Tugas 1 Membangun Konteks

Sebelum membaca teks ini, jawablah pertanyaan berikut!

1. Apa yang kamu ketahui tentang teknologi tepat guna?

2. Apakah teknologi tepat guna dapat dimanfaatkan untuk memberdayakan ekonomi keluarga?

3. Bagaimana mengupayakan supaya teknologi tepat guna bermanfaat bagi kehidupan?

4. Sebutkan jenis dan manfaat teknologi tepat guna!

5. Ceritakanlah pengalamanmu secara lisan ketika menggunakan alat yang berhubungan dengan listrik!"

(Buku teks Bahasa Indonesia, Hal:18)

Teks di atas menunjukkan bahwa antara pokok bahasannya yakni Teknologi Tepat Guna dan Pemberdayaan Ekonomi Masyarakat dengan sub bahasannya mengenai teks eksposisi yang berhubungan dengan teknologi tepat guna memiliki ketertautan atau hubungan. Artinya sub bahasan yang ada tidak berbeda dengan topik yang disajikan.

3. Kesesuaian Penyajian 
Instrumen ke 3 dalam artikel ini yakni kesesuaian penyajian. Dalam kesesuaian ini terbagi menjadi 2, yakni berdasarkan isi materi dan berdasarkan bahasa. Penyajian berdasarkan isi materi dan bahasa ini masing - masing terdapat 3 sub komponen yang sama dalam penilaian yakni teknik penyajian, penyajian pembelajaran serta kelengkapan penyajian yang memiliki deskripsi yang berbeda.

Tabel

Tingkat Kesesuaian Penyajian dalam Buku Teks

\begin{tabular}{|c|c|c|c|}
\hline $\begin{array}{c}\text { SUB } \\
\text { KOMPONEN }\end{array}$ & BUTIR & SKOR & KET \\
\hline \multirow{3}{*}{$\begin{array}{l}\text { Teknik } \\
\text { penyajian }\end{array}$} & keruntutan konsep & 3 & $S$ \\
\hline & Konsistensi sistematika & 4 & SS \\
\hline & Keseimbangan antar bab & 3,3 & S \\
\hline \multirow{4}{*}{$\begin{array}{l}\text { Penyajian } \\
\text { pembelajaran }\end{array}$} & Berpusat pada peserta didik & 3,3 & S \\
\hline & $\begin{array}{l}\text { Mengembangkan ketererampilan } \\
\text { proses }\end{array}$ & 2,7 & S \\
\hline & $\begin{array}{l}\text { Memperhatikan aspek keselamatan } \\
\text { kerja }\end{array}$ & 3,6 & SS \\
\hline & Variasi Penyajian & 4 & SS \\
\hline \multirow{6}{*}{$\begin{array}{l}\text { Kelengkapan } \\
\text { penyajian }\end{array}$} & Pendahuluan & 4 & SS \\
\hline & Daftar isi & 4 & SS \\
\hline & Glosarium & 4 & SS \\
\hline & Daftar Pustaka & 4 & SS \\
\hline & Rangkuman dan Peta Konsep & 2,3 & KS \\
\hline & Evaluasi & 3,3 & S \\
\hline
\end{tabular}


20 | ESTETIK, Vol. 1 No. 1, Juni 2018

ISSN 2622-1810 (p) 2622-1829 (e)

\begin{tabular}{|c|c|c|c|}
\hline & Proporsi dan gambar teks yang tepat & 2,3 & KS \\
\hline & Ilustrasi yang mendukung pesan & 3 & $\mathrm{~S}$ \\
\hline \multirow{3}{*}{$\begin{array}{l}\text { Teknik } \\
\text { penyajian }\end{array}$} & Keruntutan konsep & 3 & $S$ \\
\hline & Kekonsistenan sistematika & 3,3 & $\mathrm{~S}$ \\
\hline & Keseimbangan antar bab & 3 & $\mathrm{~S}$ \\
\hline \multirow{4}{*}{$\begin{array}{l}\text { Penyajian } \\
\text { pembelajaran }\end{array}$} & Berpusat pada peserta didik & 3 & S \\
\hline & $\begin{array}{l}\text { Mengembangkan keterampilan } \\
\text { proses }\end{array}$ & 3 & $S$ \\
\hline & $\begin{array}{l}\text { Memperhatikan aspek keselamatan } \\
\text { kerja }\end{array}$ & 3,6 & SS \\
\hline & Variasi penyajian & 3,3 & $\mathrm{~S}$ \\
\hline \multirow{8}{*}{$\begin{array}{l}\text { Kelengkapan } \\
\text { penyajian }\end{array}$} & Pendahuluan & 4 & SS \\
\hline & Daftar Isi & 4 & SS \\
\hline & Glosarium & 4 & SS \\
\hline & Daftar Pustaka & 4 & SS \\
\hline & Rangkuman dan peta konsep & 2,7 & $\mathrm{~S}$ \\
\hline & Evaluasi & 3 & $\mathrm{~S}$ \\
\hline & Proporsi dan gambar & 3 & $\mathrm{~S}$ \\
\hline & Ilustrasi yang mendukung pesan & 3,6 & SS \\
\hline \multicolumn{2}{|l|}{ Jumlah Skor } & 101,3 & $\mathrm{~S}$ \\
\hline \multicolumn{2}{|l|}{ Nilai } & 3,37 & \\
\hline
\end{tabular}


Berdasarkan penilaian di atas, maka kelayakan penyajian dalam buku teks Bahasa Indonesia untuk kelas VII terbitan Kemdikbud termasuk dalam kategori sesuai. Pada aspek ini memiliki 30 butir penilaian yang tidak hanya termasuk kategori sesuai dan sangat sesuai namun, ada butir penilaian yang termasuk kategori kurang sesuai.

Teknik penyajian dalam buku ini terlihat runtut, setiap bab dimulai dari konsep yang sederhana atau mudah hingga konsep yang sulit. Artinya ada penyajian konsep-konsep materi yang mudah di pahami siswa hingga akhirnya siswa menemukan konsep yang cukup sulit dalam setiap bab. Sitematika yang digunakan juga konsisten dari bab 1 sampai bab terakhir. Setiap bab di mulai dari pendahuluan, isi dan penutup yang akhirnya akan merujuk kepada evaluasi. Keseimbangan antar bab juga terlihat dalam buku ini, materi-materi yang disampaikan sesuai dengan tuntutan KI dan KD yang ada. Proporsi penyajian setiap materi yang seimbang dengan kegiatan siswa dalam tugas - tugas serta evaluasi.

Buku ini menggunakan ilustrasi-ilustrasi yang mendukung pesan atau wacana yang disampaikan dan ilustrasi tersebut selalu mencantumkan sumbernya. Namun, semua sumbernya diambil dari internet, yang terkadang tidak selalu memenuhi karakteristik materi dan tujuan pembelajaran serta sebagian gambar yang warnanya kurang jelas. Adapun penyajian ilustrasi yang cukup sesuai dapat dilihat pada contoh di bawah ini.

Contoh Kesesuaian Penyajian Ilustrasi yang Kurang Sesuai

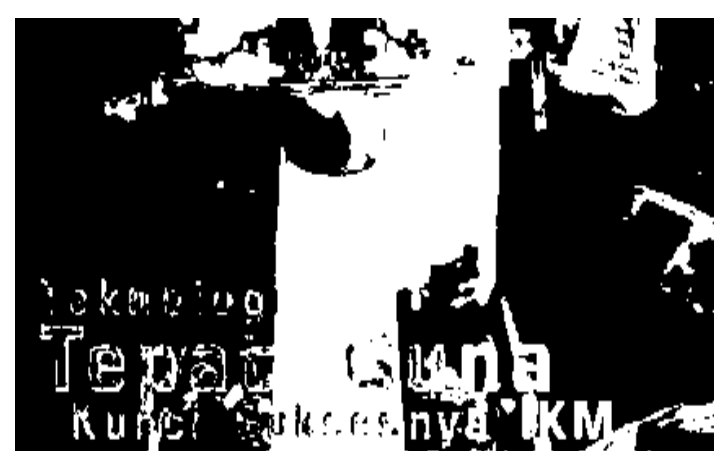

Gambar Teknologi Tepat Guna

Sumber www.ttg.lipi.go.id 


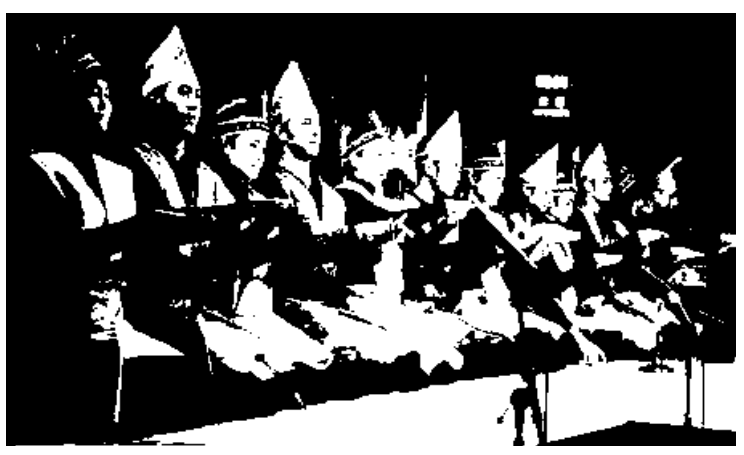

Gambar Tari Saman

Sumber http://www.investor.co.id

Contoh di atas merupakan ilustrasi yang kurang sesuai. Pada gambar Tari Saman, warna yang kurang jelas akan mempengaruhi tugas yang akan dikerjakan oleh peserta didik. Tugas yang terdapat pada bagian bawah gambar tersebut berkaitan dengan kostum, bentuk, warna baju serta fungsi bagian kostum. Tidak berbeda jauh dengan gambar mengenai teknologi tepat guna, gambar tersebut kurang jelas menggambarkan apa, padahal di dalam teks disebutkan teknologi cara pembuatan susu kedelai. Jadi, apabila warna pada ilustrasi tidak jelas maka akan berdampak pada hasil yang akan dicapai siswa pada evaluasi pembelajaran.

Selanjutnya alur peta konsep yang ada pada awal setiap bab masih kurang jelas. Kelengkapan penyajian buku ini secara umum sudah lengkap karena terdapat pendahuluan, daftar isi, glosarium, daftar pustaka, ringkasan, dan evaluasi. Soal-soal yang digunakan dalam evaluasi pada buku ini terbilang cukup baik karena memacu siswa untuk berpikir kreatif dan logis dalam kegiatan belajar yang mereka lakukan sesuai dengan tuntutan indikator pembelajaran. Berikut ini contoh evaluasi yang sesuai dari segi penyajian.

\section{Contoh Kesesuaian Penyajian yang Sesuai}

“Tugas 1 Menyusun Teks Eksplanasi

Kegiatan menyusun teks secara mandiri dilakukan dalam dua tahap, yaitu tulis dan lisan. Teks yang akan kamu tulis harus sesuai dengan struktur teks eksplanasi. Setelah teks eksplanasi yang kamu 
susun itu sempurna, kamu diminta menyampaikannya secara lisan dengan pengucapan dan intonasi yang benar.

1. Untuk tugas tulis, lakukanlah tugas berikut sesuai urutan!

a. Tentukanlah topik yang akan kamu tulis!

b. Tulislah ide-ide pokok sesuai struktur teks eksplanasi!

c. Buatlah kerangka teks eksplanasi!

d. Kembangkanlah kerangka teks eksplanasi berdasarkan ide pokok pada butir b)!

e. Gunakanlah kaidah bahasa Indonesia yang benar (kohesi, konjungsi, dankalimat simpleks)!

f. Lakukanlah pengecekan ulang terhadap teks yang sudah disusun, termasuk mencermati unsur kebahasaan, seperti kosakata, tata bahasa, dan tanda baca!

2. Untuk tugas lisan, coba kamu kerjakan tugas berikut!

a. Lakukanlah latihan melafalkan kata, istilah, dan lagu kalimat yang kamu anggap sulit!

b. Presentasikan hasil kerjamu di dalam kelompok (boleh membawa catatan kecil yang berisi kata-kata kunci dan urut-urutan kejadian, bisa dengan penomoran)!

c. Mintalah gurumu memeriksa hasil kerjamu itu! Kemudian, perbaikilah sesuai dengan sarannya sebelum kamu terbitkan di majalah sekolahmu!

d. Presentasikan hasil kerjamu di depan kelas (boleh membawa catatan kecil yang berisi kata-kata kunci dan urut-urutan kejadian, bisa dengan penomoran)!

Tugas 2 Mewawancarai Seseorang

Setelah memahami teks eksplanasi "Gempa Bumi" dan menyusun teks eksplanasi lain,tentu kamu ingin menerapkan Pembelajaran V ini dalam kehidupan nyata. Untuk itu,lakukanlah tugas berikut!

1. Buatlah daftar pertanyaan tentang peristiwa alam!

2. Gunakan pertanyaan tersebut untuk mewawancarai tokoh masyarakat atau teman di sekitarmu mengenai peristiwa alam yang kamu ketahui! Kemudian, tulislah hasil wawancara itu dalam kaidah bahasa Indonesia yang benar! “

(Fairul Zabadi dkk, 2013: .... ) 
ISSN 2622-1810 (p) 2622-1829 (e)

Contoh penyajian dari segi bahasanya, evaluasi di atas dapat dikatakan sesuai, karena bahasa yang digunakan mudah di pahami oleh peserta didik dan tugasnya pun runtut dari awal sampai akhir, serta tugas yang terbagi menjadi 2 bagian, yakni lisan dan tertulis yang disajikan secara lengkap setiap tahapannya. Sehingga keterampilan berbicara dan keterampilan menulis peserta didik dapat terukur dengan baik.

\section{Kesesuaian Kegrafikan}

Kesesuaian kegrafikan dalam artikel buku teks Bahasa Indonesia kelas VII terbitan Kemdikbud ini memuat 6 komponen penilaian, diantaranya ukuran buku, desain kulit buku, tipografi kulit desain isi buku, tipografi dan ilustrasi isi.

Tabel

Tingkat Kesesuaian Kegrafikan dalam Buku Teks

\begin{tabular}{|c|c|c|c|}
\hline $\begin{array}{c}\text { SUB } \\
\text { KOMPONEN }\end{array}$ & BUTIR & SKOR & KET \\
\hline \multirow[t]{2}{*}{ Ukuran } & $\begin{array}{l}\text { Kesesuaian buku dengan standar ISO } \\
(\mathrm{A} 4, \mathrm{~A} 5, \mathrm{~B} 5)\end{array}$ & 4 & SS \\
\hline & $\begin{array}{l}\text { Kesesuaian ukuran dengan materi isi } \\
\text { buku }\end{array}$ & 4 & SS \\
\hline \multirow[t]{3}{*}{$\begin{array}{l}\text { Desain kulit } \\
\text { buku }\end{array}$} & $\begin{array}{l}\text { Penampilan tata letak pada kulit muka, } \\
\text { belakang dan punggung secara } \\
\text { harmonis, memiliki irama dan kesatuan } \\
\text { (unity), serta konsisten (sesuai pola). }\end{array}$ & 3 & $\mathrm{~S}$ \\
\hline & Menampilkan pusat pandang yang baik & 2,3 & KS \\
\hline & $\begin{array}{l}\text { Komposisi dan ukuran unsur tata letak } \\
\text { (judul, pengarang, ilustrasi, logo), } \\
\text { proporsional, seimbang dan seirama }\end{array}$ & 4 & SS \\
\hline
\end{tabular}




\begin{tabular}{|c|c|c|c|}
\hline & \multicolumn{3}{|l|}{ dengan tata letak isi (sesuai pola). } \\
\hline & $\begin{array}{l}\text { Warna unsur tata letak harmonis dan } \\
\text { memperjelas fungsi. }\end{array}$ & 4 & SS \\
\hline \multirow[t]{7}{*}{$\begin{array}{l}\text { Tipografi } \\
\text { Kulit }\end{array}$} & $\begin{array}{l}\text { Ukuran huruf judul buku lebih dominan } \\
\text { dan proporsional dibandingkan ukuran } \\
\text { buku, nama pengarang, dan penerbit }\end{array}$ & 3 & $S$ \\
\hline & $\begin{array}{l}\text { Warna judul buku kontras dengan } \\
\text { warna latar belakang }\end{array}$ & 4 & SS \\
\hline & $\begin{array}{l}\text { Tidak menggunakan terlalu banyak } \\
\text { kombinasi jenis huruf }\end{array}$ & 3,6 & SS \\
\hline & $\begin{array}{l}\text { Tidak menggunakan huruf hias dan } \\
\text { jenis huruf sesuai huruf isi buku. }\end{array}$ & 4 & SS \\
\hline & Mengungkapkan karakter obyek & 3,3 & $\mathrm{~S}$ \\
\hline & $\begin{array}{l}\text { Menggambarkan isi / materi ajar dan } \\
\text { mengungkapkan karakter obyek. }\end{array}$ & 3 & $\mathrm{~S}$ \\
\hline & $\begin{array}{l}\text { Bentuk, warna, ukuran, proporsi obyek } \\
\text { sesuai realita }\end{array}$ & 2,7 & $\mathrm{~S}$ \\
\hline \multirow[t]{5}{*}{$\begin{array}{l}\text { Desain isi } \\
\text { buku }\end{array}$} & $\begin{array}{l}\text { Penempatan unsur tata letak konsisten } \\
\text { berdasarkan pola }\end{array}$ & 4 & SS \\
\hline & Pemisahan antar paragraf jelas & 4 & SS \\
\hline & Bidang cetak dan margin proporsional & 4 & SS \\
\hline & $\begin{array}{l}\text { Margin antara dua halaman } \\
\text { berdampingan proporsional }\end{array}$ & 4 & SS \\
\hline & Spasi antara teks dan ilustrasi sesuai & 4 & SS \\
\hline
\end{tabular}




\begin{tabular}{|c|c|c|c|}
\hline & $\begin{array}{l}\text { Judul bab, sub judul bab dan angka } \\
\text { halaman. }\end{array}$ & 4 & SS \\
\hline & $\begin{array}{l}\text { Ilustrasi dan keterangan gambar } \\
\text { (caption) }\end{array}$ & 3,6 & SS \\
\hline & $\begin{array}{l}\text { Penempatan hiasan / ilustrasi sebagai } \\
\text { latar belakang tidak mengganggu judul, } \\
\text { teks, angka halaman. }\end{array}$ & 4 & SS \\
\hline \multirow[t]{9}{*}{ Tipografi } & $\begin{array}{l}\text { Penempatan judul, subjudul, ilustrasi } \\
\text { dan keterangan gambar tidak } \\
\text { mengganggu pemahaman. }\end{array}$ & 4 & SS \\
\hline & $\begin{array}{l}\text { Tidak menggunakan terlalu banyak } \\
\text { jenis huruf }\end{array}$ & 4 & SS \\
\hline & $\begin{array}{l}\text { Tidak menggunakan jenis huruf } \\
\text { hias/dekoratif }\end{array}$ & 4 & SS \\
\hline & $\begin{array}{l}\text { Penggunaan variasi huruf (bold, italic, } \\
\text { capital) tidak berlebihan. }\end{array}$ & 4 & SS \\
\hline & $\begin{array}{l}\text { Jenis huruf sesuai dengan pendidikan } \\
\text { peserta didik }\end{array}$ & 4 & SS \\
\hline & $\begin{array}{l}\text { Lebar susunan teks sesuai dengan } \\
\text { pendidikan peserta didik }\end{array}$ & 3 & $S$ \\
\hline & Spasi antar baris susunan teks normal. & 4 & SS \\
\hline & $\begin{array}{l}\text { Jenjang / hierarki judul - judul jelas, } \\
\text { konsisten, proporsional }\end{array}$ & 3,3 & $S$ \\
\hline & $\begin{array}{l}\text { Tanda pemotongan kata disesuaikan } \\
\text { dengan tingkat pemahaman siswa }\end{array}$ & 3 & S \\
\hline
\end{tabular}




\begin{tabular}{|l|l|c|c|}
\hline Ilustrasi isi & $\begin{array}{l}\text { Mampu mengungkapkan makna/arti } \\
\text { dan objek }\end{array}$ & 3 & $\mathrm{~S}$ \\
\cline { 2 - 4 } & $\begin{array}{l}\text { Bentuk akurat dan proporsional sesuai } \\
\text { dengan kenyataannya. }\end{array}$ & 2,3 & $\mathrm{KS}$ \\
\cline { 2 - 4 } & Penyajian keseluruhan ilustrasi serasi & 3 & $\mathrm{~S}$ \\
\cline { 2 - 4 } & kreatif dan dinamis. & 3 & $\mathrm{~S}$ \\
\hline Jumlah Skor & & 120,7 & $\mathrm{SS}$ \\
\hline Nilai & 3,52 & \\
\hline
\end{tabular}

Instrumen ke 4 yang digunakan dalam penilaian adalah kesesuaian kegrafikan. Berdasarkan tabel di atas menunjukkan bahwa kesesuaian kegrafikan termasuk dalam kategori sangat sesuai namun dari ke 34 butir yang dalam kesesuaian ini tidak hanya termasuk dalam kategori sangat sesuai melainkan ada juga yang termasuk kategori sesuai dan kurang sesuai.

Kesesuaian isi pada buku Bahasa Indonesia terbitan Kemendikbud ini termasuk kedalam kategori sesuai. Aspek ini memuat materi- materi yang disajikan secara tepat dalam sebuah buku teks, ini merupakan hal yang sangat penting bagi peserta didik karena akan berpengaruh terhadap pemahaman peserta didik. Buku teks yang baik tentunya memperhatikan hal tersebut, dan mengacu kepada kurikulum yang ada, ilmu yang relevan serta kebutuhan bahasa pembelajar (Harimansyah, 2008: 80).Dalam buku teks bahasa Indonesia ini kesesuaian isi secara garis besar sudah menunjukkan kesesuaian dengan KI dan KD yang ada, dan menampilkan wacana yang bervariasi dan terbaru sehingga memicu daya pikir peserta didik dalam memahami pengetahuan. Daya tarik ilustrasi yang baik dan tepat dengan teks yang kontekstual (akrab dengan lingkungan peserta didik) juga akan menunjang kemampuan siswa untuk memahami lebih dalam sebuah teks yang disajikan. 
Sebuah buku teks tidak cukup hanya memiliki kesesuaian dalam materi saja, tetapi yang paling penting juga adalah kesesuaian bahasa yang digunakan dalam menyampaikan materi-materi tersebut. materi yang disajikan dari segi bahasa dalam buku ini sudah sesuai. Bahasa yang digunakan ditentukan oleh tingkat kemampuan peserta didik dan menggunakan bahasa yang standar artinya bahasa tersebut efektif, tidak makna ganda, menarik, sopan (Tarigan \&Tarigan, 2009: 23). Bila bahasa yang digunakan tidak efektif dan tidak sesuai dengan tata bahasa yang baik tentunya akan mengurangi tingkat pemahaman peserta didik dalam memperoleh ilmu.

Selain ketepatan bahasa dan ketepatan isi, sebuah buku yang baik juga harus memiliki konsep penyajian yang dapat menarik perhatian peserta didik. Aspek kesesuaian kegrafikan dalam buku teks ini dikategorikan sesuai. Menurut Tarigan \& Tarigan (Tarigan \& Tarigan, 2009: 23) , buku teks yang baik adalah buku yang dapat membuat siswa ingin, mau, senang mengerjakan apa yang diinstruksikan dalam buku teks dan menambah ketertarikan siswa dalam pembelajaran tersebut. Penyajian dalam sebuah teks yang mampu merangsang daya pikir dan kreasi peserta didik adalah sebuah buku teks yang sesuai. Penyajian ini dilihat dari awal buku sampai akhir.

Penampilan fisik sebuah buku tidak kalah pentingnya dari aspek bahasa, isi dan penyajian. Fisik sebuah buku akan mendukung ketertarikan siswa pada buku tersebut. Aspek kegrafikan pada buku teks ini termasuk kategori sangat sesuai. Bila sebuah buku dirancang dengan sedemikian rupa, dengan sampul atau cover, kolaborasi warna, ilustrasi, tampilan setiap bab yang menarik, maka akan memikat peserta didik, dan mendorong mereka untuk membaca buku teks ini, yang pada akhirnya akan berdampak pada peningkatan pemahaman peserta didik dalam belajar bahasa Indonesia.

\section{Simpulan}

Berdasarkan hasil dan pembahasan, maka dapat disimpulkan bahwa:

a Kesesuaian isi Buku teks Kurikulum 2013 yang digunakan di SMP kelas VII menunjukkan kategori sesuai dari segi kesesuaian materi, keakuratan materi dan pendukung materi. Namun, 
kesesuaian isi ini perlu revisi sedikit pada bagian keakuratan ilustrasinya.

b Kesesuaian bahasa Buku Teks Kurikulum 2013 yang digunakan di SMP kelas VII termasuk kategori sesuai dari segi aspek kesesuaian dengan tingkat perkembangan peserta didik, ketepatan tata bahasa, kebakuan istilah, keruntutatan bab dan ketertautan antar bab. Selain itu, ada bagian yang perlu direvisi yakni, kesesuaian dengan tingkat perkembangan intelektual peserta didik dan keterpahaman pesannya.

c Kesesuaian penyajian Buku Teks Kurikulum 2013 yang digunakan di SMP kelas VII termasuk kategori sesuai dari aspek teknik penyajian, penyajian pembelajaran, kelengkapan penyajiannya. Bagian yang perlu direvisi pada kesesuaian penyajian ini yaitu bagian kelengkapan penyajian berdasarkan isinya.

d Kesesuaian kegrafikan Buku Teks Kurikulum 2013 yang digunakan di SMP kelas VII menunjukkan kategori sangat sesuai dari aspek ukuran, tipografi kulit, desain isi buku dan ilustrasi isinya. Namun, perlu revisi sedikit pada bagian desain kulit buku agar memberikan pusat pandang yang baik bagi peserta didik.

\section{Daftar Pustaka}

Altbach, P.G. 1991. Textbooks in American Society: Politics, Policy, and Pedagogy. Buffalo: SUNY Press.

Departemen Pendidikan Nasional, Pusat Perbukuan. 2005. Peraturan Menteri Pendidikan Nasional Nomor 11 tahun 2005 tentang Buku Teks Pelajaran

Hatikah, Tika dan Mulyanis. 2003. Berbahasa dan Sastra Indonesia Untuk SMUKelas II Semester 2. Jakarta: Grafindo Media Pratama.

Kurniati, Nia. 2011. Bahasa Indonesia Kebanggaanku Kelas IV. Bandung: Eka Cipta Setosa

Krippendorf, klaus. 1993. Buku Pelajaran Bahasa Indonesia SD. Jakarta: Grasindo.

Muslich, Mansur. 2010. Text Book Writing: Dasar - Dasar Pemahaman, Penulisan, dan Pemakaian Buku Teks. Yogyakarta: Ar-Ruzz Media. 
30 | ESTETIK, Vol. 1 No. 1, Juni 2018

ISSN 2622-1810 (p) 2622-1829 (e)

Muzakir.2010. Penulisan Buku Teks Yang Berkualitas (artikel jurnal online).http//www.google.com/File.upi.ede/Direktori/FPBS/JUR. Diakses 22 November 2013, 20.00 WIB.

Panduan Penyusunan KTSP.2006 BNSP.

Prastowo, Andi. 2011. Panduan Kreatif Membuat Bahan Ajar Inovatif. Yogyakarta: Diva Press

Pusat Perbukuan. 2002. Pedoman Pengembangan Standar Perbukuan. Departemen Pendidikan Nasional

Sugiyono. 2007. Metode Artikel Kuantitatif, Kualitatif Dan $R$ \& D. Bandung: Alfabeta

Sukardi, 2008. Metodologi Artikel Pendidikan kompetensi dan Praktiknya. Jakarta: Bumi Angkasa 